\title{
EVALUATING A PORTFOLIO OF PROJECTS THROUGH THE REAL OPTIONS ANALYSIS"
}

\author{
Aleksandr B. LANCHAKOV ${ }^{\mathrm{a}}$, Sergei A. FILIN ${ }^{\mathrm{b},}$, Aleksei Zh. YAKUSHEV \\ ${ }^{a}$ Moscow Institute of Physics and Technology (State University) (MIPT), \\ Dolgoprudny, Moscow Oblast, Russian Federation \\ ab5657171@yandex.ru \\ https://orcid.org/0000-0001-8563-7817 \\ ${ }^{\mathrm{b}}$ Plekhanov Russian University of Economics (PRUE), \\ Moscow, Russian Federation \\ Filin.SA@rea.ru \\ https://orcid.org/0000-0002-6054-6510 \\ c Plekhanov Russian University of Economics (PRUE), \\ Moscow, Russian Federation \\ Yakushev.AZH@rea.ru \\ https://orcid.org/0000-0003-0371-0289
}

- Corresponding author

Article history:

Article No. 159/2020

Received 19 March 2020

Received in revised form

3 April 2020

Accepted 23 April 2020

Available online

29 September 2020

JEL: G19

\section{Keywords:}

investment portfolio, innovative project, real options method, expected effect

\begin{abstract}
Subject. The article analyzes the expected effect of a portfolio of projects in the face of risk and uncertainty, when using real options.

Objectives. The purpose is to offer a more objective formula to assess the expected impact of a portfolio of projects for real investment objects under risk and uncertainty, using real options, and provide recommendations for improving the portfolio efficiency.

Methods. The study draws on methods of real options and evaluation of investment projects through the real option value, the cash flow discounting method, synthesis, and mathematical modeling.

Results. We systematized the main types of real options and developed a formula for calculating the expected effect of project portfolio implementation. The said formula shows that considering the additional longterm costs embedded in a portfolio of real options, which are associated with the use of these real options, and, therefore, reducing the overall risk of projects and the entire portfolio, permit to improve the objectivity of such calculations.

Conclusions. When analyzing real options that have real assets as underlying instruments, it is often impossible to apply the computational formulae for financial options, as they differ significantly. The systematization of the main types of real options helps expand the range of application of management solutions. The offered formula enables to improve the efficiency of project insurance under risk and uncertainty and to use additional opportunities for effective development of the company.
\end{abstract}

(c) Publishing house FINANCE and CREDIT, 2020

The editor-in-charge of this article was Irina M. Vechkanova

The authorized translation by Irina M. Vechkanova

Please cite this article as: Lanchakov A.B., Filin S.A., Yakushev A.Zh. Evaluating a Portfolio of Projects Through the Real Options Analysis. Digest Finance, 2020, vol. 25, iss. 3, pp. 246-260.

https://doi.org/10.24891/df.25.3.246 
Implying the passive management (an algorithm of actions predetermined at the initial phase of its implementation), techniques of the traditional investment project study overlook the possibility of synergistic positive effects. Therefore, classical methods underestimate investment opportunities, neglecting that the manager may change an initial managerial and/or investment decision, referring to the new information. This should be predicted. From perspectives of the real options theory, the project study [1-7] is an attempt to find additional opportunities.

Basically, the options theory holds that projects bring two groups of opportunities. First, project conditions may change over time, such as the expansion (reduction) of the project, changes in resources and raw material, project rejections upon the receipt of new information, etc. The second group refers to the surrounding environment of the project. For example, if some project is unfeasible unless another project is performed. Therefore, in the broad sense, the opportunity can be measured. The more opportunities the project opens, the more valuable it is.

Considering the uncertainty of the external environment and other properties of the project, different versions of cash flows are feasible, thus giving way to different views of the efficiency. This complicates managerial and/or investment decision-making and substantiation of the decision given traditional methods are used. In this case, the real (embedded, implicit) options method ${ }^{1}$ may turn one of the most important means of creating more adequate tools for investment studies, which provide for the flexibility of managerial and/or investment decisions [8-10]. The real options method confers the options pricing, which is widely used in stocks markets, to the management of an investment portfolio ${ }^{2}$ that contains items of real investment in terms of its hedging $[11,12]$.

The real options analysis works for the valuation of major strategic projects, which are planned for decades. For example, the construction of new communication lines. In such cases, project scenarios are analyzed, with each aspect bringing a potential damage or economic effect, as circumstances may be. It is important to predict the entire range of effects - positive or negative - and the probability of scenarios. This, indeed, gives great opportunities of deriving higher economic benefits, reaching technological solutions or indemnification, which are treated as a set of real options under the project [13].

The real options analysis of the investment project is frequent in case of a material uncertainty in the market development [14]. For instance, it is reasonable to evaluate and consider real options for items of real investment in order to make up a portfolio of real

\footnotetext{
"For the source article, please refer to: Ланчаков А.Б., Филин С.А., Якушев А.Ж. Оценка портфеля проектов при использовании реальных опционов // Финансовая аналитика: проблемы и решения. 2020. Т. 13. № 2. C. 126-146. URL: https://doi.org/10.24891/fa.13.2.126

${ }^{1}$ This is the method to quantify the lucrativeness of a project as the value of a stock option contract.

${ }^{2}$ The investment project portfolio is a set specially made for purposes of investing activity in line with the investment strategy of the firm. It is mainly formed to implement the investment strategy by selecting the most effective projects.
} 
options more effectively, when developing each of the projects in the investment portfolio and the overall portfolio.

The discounted cash flow method (DCF method) ${ }^{3}$ indirectly implies that the firm holds real assets, without considering real options embedded therein and available to gain competitive advantages. So, the DCF method is static and provides for the conservative approach to analyzing the investment situation, without accounting for the possibility of any changes in managerial and/or investment decisions, which, for example, may arise during the project performance. Seizing such opportunities, the firm has several project performance scenarios. However, the scenario-based analysis and ordinary approaches do not address dynamic changes in items of real investment and uncertainty of the external environment. Thus, the average version is accepted to show how the uncertainty of the project performance will be taken into consideration in accordance with respective assumptions. When the DCF method is applied, it gets difficult to cancel some actions put on the business plan during the project so as to gain new opportunities of more successful project outcomes and corporate development as a whole.

Opposed to the DCF method for purposes of project studies, the real options method helps appraise opportunities that the company has, and project-related investment and other risks so as to utilize investment resources as effectively as possible. The uncertainty is still there, but managers can adapt to the developing situation. It means that the real options method helps make more effective managerial and/or investment decisions in the future as new information comes, and evaluate them during the initial analysis of the project feasibility.

If the company uses the real options method for purposes of corporate governance, it will decreases the importance of expensive high-precision forecasts and take efforts to determine alternative development paths.

Let us analyze real options for real projects, which allow managers to increment the corporate value, find new opportunities or decrease losses (Fig. 1).

The availability of real options for the decline of a real innovation project (a withdrawal from the project) to an extent hedges against any failure to implement it further. It can be treated as a real put option with the strike price equal to the value of the innovation project's assets in case of their disposal or more beneficial use. Holding the option, the firm can leave the project in case of the market deterioration by selling assets, reimbursing some of its losses or using them for other more profitable investment. The venture fund can withdraw from the project in case of its successful implementation through a stock market mechanism, with the gains being used as the income of owners

\footnotetext{
${ }^{3}$ The DCF method was initially intended for stocks and ordinary bonds. They can be sold, but this actually means the substitution of investors. Options and convertible bonds with embedded options considerably differ from stocks and ordinary bonds. Investors, which hold bonds, get the right to make decisions in order to benefit from favorable circumstances or decrease their losses.
} 
and compensation to managers of the venture fund and investment in other innovative projects.

Let us look at the computation of a real option for the decline of an innovative project. For instance, the firm implements a new production project, while optimizing its mix of goods, decreasing the cost of goods sold and expanding the distribution market. Fig. 2 displays the analysis of decision-making phases concerning the real option for the decline of the innovative project.

As per the computation, the firm makes investment decisions at the end of each year. Each ramification means a point of an investment decision or another milestone. Net investment is represented with the figure in round brackets to the left of the decisionmaking point. The interval from the third to the sixth years (from $t=3$ through $t=6$ ) indicates the influx of cash generated by the project.

Investment in the project takes three steps.

Step 1. For example, if the firm chooses to implement the project at $t=0$, it has to spend RUB 50 thousand on marketing research. According to managers' estimates, there is an 80-percent probability of a good result, while the unfavorable one is possible in 20 percent of cases. If the project is suspended at this point, it will cost RUB 50 thousand for the firm.

Step 2. If, based on its marketing research, the firm gets a positive impression of the market potential, then at $t=1$ it has to spend another RUB 100 thousand to manufacture a testing sample of its products. According to managers' estimates, positive and negative outcomes are possible as $60 \%$ to $40 \%$ respectively.

Step 3. If design experts and potential consumers are satisfied with the new product, the company at $t=2$ must invest RUB 1 million to purchase new equipment for manufacturing new products and the launch of production. Managers believe in a 40percent and 60-percent probability that design experts and potential consumers will be and will not be satisfied with new products respectively (which will mean the project termination). If a firm launches a new product, project managers estimate that operating cash flows will be generated within four years of the project's life, and their amount will depend on the market success of the new product. The probability that the product will be well received by the market is 30\%, meaning net cash flows should be about RUB 1 million per year. Cash flows will be about RUB 400 thousand and 200 thousand a year (40\% and 30\%, respectively). These expected cash flows are shown in Fig. 2 from the third to the sixth year.

The joint probability measured at the output (Fig. 2) indicates the expected probability of each result. Upon the completion of the project, NPV = RUB 1,525 thousand and the probability of 0.144 (Fig. 2). 
However, the costs of the project suspension are significantly reduced to RUB 50 thousand in case of the probability of 0.2 and RUB 137.9 thousand in case of the probability of 0.32 . If in this case the firm has an alternative to use the assets of this project, for example, it could use equipment to manufacture an absolutely different type of a product, then the new production project could be terminated at lower losses and project risk.

Investment in an innovative project is a dynamic process. At each nodal point of the decision tree, the conditions for its implementation can differ, causing a change in NPV immediately.

An option for non-released new products allows the innovative firm to secure an interestfree loan, with the buyer-broker making a partial prepayment. The development and release of new products require significant investments. Experts on the Tyumen-Moscow Exchange have developed a methodology for trading in non-finished products of an innovative company, thus putting up for bidding a bunch of options for a new product that has not yet been produced. In this case, having paid $20-40 \%$ of the cost of the entire batch, the buyer obtains the right to distribute it as it is produced. The remaining $60-80 \%$ of the cost are paid as the new product is delivered ${ }^{4}$. The contract stipulates that if the company refuses to supply a new product, the interest-free loan turns into a commercial one with a rate not lower than on commercial bank loans. The option for non-manufactured new products also stipulates a reduction in the current prices, and in the event of their increase, it provides for the redistribution of income from the sale of products between the manufacturer and the buyer.

The options-based investment strategy in the case of the item of real investment can be illustrated with the use of a real option contract as a component of a lease contract ${ }^{5}$ [15]. In this case, when contracting with the lessee, the lessor can enter into a put option contract with a third party, that is, the real option for the disposal of any item of real investment (such as equipment) as part of the firm's investment project.

Real options are a traditional tool for selling technically complex and expensive weapons and vehicles. On the one hand, they allow to plan and finance production, and, on the other hand, the buyer has the ability to both receive the ordered goods and refuse to receive them. A real option per se as a right to receive goods is also a commodity that can be resold.

\footnotetext{
${ }^{4}$ Goncharenko L.P., Filin S.A., Kuznetsov B.T. et al. Innovatsionnyi menedzhment [Innovation Management]. Moscow, Russian Academy of Sciences, Russian Academy of Education, Institute of Scientific and Pedagogical Information, Science and Education Foundation, 2015.

${ }^{5}$ Gracheva Yu.A. [Assessing the financial risk of the lessee in case of the early termination of the lease contract and methods to mitigate it]. Investitsii i ekonomicheskaya bezopasnost': materialy Investitsii i ekonomicheskaya bezopasnost' XIV Mezhdunarodnykh Plekhanovskikh chtenii [Proc. Sci. Conf. Investment and Economic Security. 14th International Plekhanov Readings]. Moscow, Russian State University of Economics Publ., 2001, pp. 112-125. (In Russ.)
} 
For example, the State Transport Leasing Company (GLTK) entered into a firm contract for the purchase of 32 Sukhoi SuperJet 100 aircraft from the United Aircraft Corporation. The agreement provided for the delivery of 32 aircraft by the end of 2017, as well as an option for 28 additional airliners. The planes were to be transferred under operating leases to Russian regional airlines, the first of which was the Yamal air carrier. The leasing operator immediately signed a contract for the sale of 25 airliners to Yamal and a letter of intent with the Kazakh carrier Scat Airlines, which may become the largest buyer of the Sukhoi SuperJet acquired by GTLK, on the sale of 15 aircraft under the option contract $^{6}$.

Real options can be sold by stock speculators, which expect the lessor insufficiently demand the option right to derive a profit under this option contract in the form of an option premium, or potential buyers who want to purchase this item of real investment at a price below the market one. A real option allows the lessor, within the agreed period of the option contract, to sell the item of real investment to the seller of the real option at the price specified in the contract (strike price). Moreover, this option confers only the right to sell on its buyer, rather than an obligation, that is, the performance or nonperformance of the option contract depends entirely on the lessor. In this case, the seller of the real option is obliged to buy the item of real investment at the strike price set by parties with reference to the market value of the leased asset upon the expiration of the real option, taking into account its physical and moral obsolescence. It remains unchanged during the entire period of the real option. That is, the lessor can get secure themselves against the lessee's failure to fulfill the lease contract by selling the leased item at a fixed price. In this case, the premium the seller of the real option is paid can be included into lease payments as a sum insured as part of the lessor's investment costs. The lessor, as the buyer of a real option, expects that the strike price will be higher than the market value of the leased asset. Thus, when purchasing a real option, the lessor should refer to forecasts of the market value of a second-hand item of real investment, thus avoiding an underestimated strike price when buying an option.

Operating lease is a real option for the lessee, which implies that the lessee can get the leased asset ahead of schedule.

One of the most important points preceding the conclusion of a license agreement takes place when the would-be buyer's experts familiarize with technical solutions to be put into commercial production. Potential buyers very often ask to present them a technical solution on the spot and demonstrate its operation. The demonstration is desirable, but it should not cause the leakage of the know-how. Otherwise it may affect the partner's decision to purchase a license or further scientific and technical cooperation. Difficulties arise from acquainting a potential licensee with the know-how technology, when negotiating a license agreement. Reading it, the licensee can refuse to conclude

\footnotetext{
${ }^{6}$ Stolyarov G. Lizingovyi gosoperator kupil u GSS 32 Superjet, poluchil optsion eshche na 28 [The public lease operator purchased 32 Sukhoi SuperJets and secured an option contract for another 28 ones]. URL: http://ru.reuters.com/article/businessNews/idRUKCN0QU1Z020150825 (In Russ.)
} 
an agreement and start using it free of charge without any liability to the owner. The potential licensee, indeed, wants to learn about the know-how technology and evaluate it before signing a license agreement [16].

As accepted internationally in the case of license trade, during talks parties should conclude a preliminary options contract, with the prepayment being made to the buyer for the know-how disclosure so as to keep it confidential and prevent the licensor from the abusive use. As per the agreement, the potential licensor undertakes to display the know-how technology to the potential licensee. If the would-be licensee learns about the know-how and refuses to sign a license agreement, they are prohibited to disclose, communicate to third parties the information that becomes known to them and use it for commercial purposes. They also lose an amount (prepayment) stipulated in the options contract and converted into the deposit in the licensor's account for the disclosure of the know-how technology. If the licensor signs the license agreement, the deposit it pays to the licensor will offset the future payments under the license agreement. Signing the options contracts, the licensee just like the licensor will need to protect the confidentiality of the know-how technology, its technological and commercial value and unavailable for competitors. Hence, trying to protect the confidentiality of the knowhow information, counterparts use the options contract during their talks to ensure the contractual protection of the know-how technology and provide for sanctions to be imposed on the licensee in case of the unauthorized use of confidential information or its commercial use. All inquiries and respective data can be circulated only upon the conclusion of options or license contracts that includes the confidentiality clause. The agreement can be a subject of a real options contract for the transfer of the knowhow technology under the license agreement as part of an innovation project [12].

Real option to hire (rent) an employee or team member. Such an options contract implies the possibility of extending, after a specified period of time, a contract with an employee of the company or a member of a sports team for their hiring (rent) for a period specified in the contract. For example, according to the $1+3$ principle (in a year for another three years) or the possible refusal to renew the contract in a year.

Real option to rescale the project. In a favorable situation (the growing number of customers, demand for products, etc.), additional investments can be made in the project, and if it deteriorates, the project can be cut, with some investment being withdrawn. Such real option contracts are advisable to apply in industries with the cyclical development.

Real (technological) option to develop new innovations as the effect of S\&T research may be, in the form of products of intellectual activity. This option is divided into three types:

- positional option provides for small investment in several technological areas simultaneously just for the case if the main direction chosen by the company does not work; 
- exploration option is used if the company can develop the technology, but is not yet sure to what extent the market will accept it;

- bridge finance option arranges for short-term and small investment in unknown market niches to use the experience gained when creating breakthrough technologies or technologies in promising market niches that appear as the company develops.

When measured with this method, the amount $i$ paid by the investor for the right to own this option represents an investment in an innovative project for the improvement and refinement of existing products and the launch of new production in technological areas, where the company already has a strong market position and image. The cost of further investment required for this project is the price $P_{0}$, which the investor has determined at time $t$, the amount of conditional profit from the project $P_{1}$ that the investor receives at time $T$.

If $P_{1} \leqslant\left(P_{0}+i\right)$, the investor would better sell the option to cover some initial costs for R\&D [14]. Deciding on a type of the option, they should consider that the option per se has no use unless the project is exposed to high risk.

Real options for items of real investment, which exist, are usually much more complicated than the above examples. For example, you can refuse to implement a real investment project at any time, and not just once. The price to be paid for such a refusal can change over time and is generally not known in advance. Furthermore, even choosing to quit the project, the investor may reassume it at a more favorable moment [15]. It is also possible to use exotic real options to protect items of real investment, for example, a compound call option ${ }^{7}$ on a project, etc. [17]

From perspectives of real options holders, the volatility contributes to the potential for growth, while the options contract limits losses. When a real project has the positive NPV, the firm attempts to exercise the real option in order to derive cash flows. If the latter are rather high, the firm will exercise the call option ahead of schedule.

Real options can be effectively used if the following basic principles of an investment portfolio are met, with respect to items of real investment ${ }^{8}$ :

- to ensure the implementation of the corporate investment strategy, the strategy should correspondingly correlate with goals of an investment portfolio (ensuring high rates of growth in the capital and income, mitigation of investment risks, sufficient liquidity of the portfolio). They need to correlate due to the consistency of long-term and mid-term planning of the firm's investing activity, dependence of mid-term plans on long-term strategic goals;

\footnotetext{
${ }^{7}$ There are call and put options, which entitle the holder to buy and sell the underlying asset.

${ }^{8}$ Goncharenko L.P., Filin S.A., Kuznetsov B.T. et al. Innovatsionnyi menedzhment [Innovation Management]. Moscow, Russian Academy of Sciences, Russian Academy of Education, Institute of Scientific and Pedagogical Information, Science and Education Foundation, 2015.
} 
- to ensure the consistency of the portfolio's capital intensity and investment resources, the capital intensity of items of real investment selected for the portfolio should correlate with the volume of investment resources generated so as to ensure the financial sustainability and leverage their sources. It causes a limited number of resources to be selected due to available finance;

- the yield to risk ratio stands for leveraging a proportion of metrics in accordance with priorities of the portfolio, which is made by diversifying items of real investment;

- leveraging the ratio of yield, liquidity and financial sustainability, the company should consider appropriate mix of the above metrics in accordance with the priorities of the portfolio and ensures the current liquidity and financial sustainability in the shortterm and long-term time horizon respectively;

- ensuring the controllability of the portfolio, the firm limits the number of items of real investment, considering the possibility to effectively sell them from perspectives of the staff capabilities of the firm.

The assessment and accounting for the value of real options for firm projects are an important mechanism for generating an investment portfolio more effectively. The project assessment is a cornerstone for making an investment decision. For this purpose, the real options concept draws upon the same metrics as the classical theory does. However, the real options concept provides for the quantification of available opportunities the project brings, thus adding them to the value. Hence, such opportunities should be taken into account when comparing projects and their indicators during the formation of an investment portfolio.

Projects are evaluated with the real options method through the assumption that any investment opportunity of the firm can be considered as a real option, i.e. the right to create or purchase (sell, return) an asset within a certain period of time. The paper [18] provides a formula to assess the value of a project given the risk and uncertainty in the use of real options. However, this formula does not accommodate for a number of long-term costs associated with the use of real options. Therefore, we present a refined formula to calculate the expected net present value of a project given the risk and uncertainty in the use of real options:

$$
\overline{N P V}=\sum_{i=1}^{n} N P V_{i} \cdot P_{i}
$$

where for investing, acquisition, use and disposal of the respective real asset $j$ in the period $t, P_{i}$ is the probability of the scenario i given $i=1, \ldots, n ; N P V_{i}$ is the net discount income under each scenario in question, which is measured as 


$$
\begin{aligned}
& N P V_{i}=\sum_{t=0}^{T} \frac{C F_{t}}{(1+E)^{t}}-\frac{S_{t}}{(1+E)^{t}}-\frac{K_{t}}{(1+E)^{t}}-\frac{M_{t}}{(1+E)^{t}}+\frac{\sum_{t=0}^{T}\left(-m_{t}-D_{t}+K_{t}\right)}{(1+E)^{t}} \\
& \sum_{t=0}^{T} \frac{C F_{t}}{(1+E)^{t}}=\sum_{t=0}^{T} \frac{R_{t}-C_{t}^{I_{t}}}{(1+E)^{t}}-\sum_{t=0}^{T} \frac{I_{t}}{(1+E)^{t}}
\end{aligned}
$$

where for investing, acquisition, use and disposal of the respective real asset $j$ in the period $t, C F_{t}$ is cash flow; $R_{t}$ means current results in monetary value, which become possible through the real asset; $C_{t}^{I t}$ means the current costs in monetary value, net of investment (in monetary value); $T$ is the horizon of assessment; $S_{t}$ is the value of embedded real options; $M_{t}$ means financial obligations for a respective real asset. If the project has debt financing, $m_{t}$ is the amount of interests paid for serving the loan in the period $t$ of the project; $D_{t}$ is the amount of the principal repaid in the period of the project; $K_{t}$ is the amount of debt financing gained in the period $t$ of the project; $E$ is the discount rate applied by the firm. Basically, it may be a general discount rate measured through the Fischer formula:

$1+E=(1+i)(1+\alpha)(1+r)$

where for investing in the acquisition, use and disposal of the respective real asset $j$ in the period $t, i$ is the nominal rate of interests on short-term government securities (bonds); $\alpha$ is the average inflation rate; $r$ means an adjustment for a non-systemic component of the general risk of the real asset.

Discounted long-standing costs $K_{t}$ relate to the use of real options, namely:

- the need to rearrange the corporate culture and business approaches;

- regular revision of business plans and the consequential loss of strategic priorities due to the excessive flexibility of managerial decision-making;

- the need for the firm to fairly account for the price to be paid for the project rejection, being, as a rule, not known in advance. The price can change over time; alternative investment costs, the value of which is comparable to the cost of a real option; the possibility of transforming costs (advertising, hiring, training and dismissal of personnel, specialized products of the service sector, purchase of equipment, etc.) into irrecoverable costs, which will make the investment ineffective and irreversible. Prudence in the case of project investment implies that this process does not start until the income from the project significantly exceeds the long-term average costs.

However, the project risk considered in formulae (1) and (2) will be lower, given real options. 
The cumulative expected effect for a portfolio of projects $L$ with embedded real options are computed as follows:

$$
\begin{aligned}
& \bar{\ni}=\sum_{l=1}^{L} N P V_{l}=\sum_{l=1}^{L} \sum_{i=1}^{n}\left[\sum_{t=0}^{T} \frac{R_{t}-C_{t}^{I_{t}}}{(1+E)^{t}}-\sum_{t=0}^{T} \frac{I_{t}}{(1+E)^{t}}-\right. \\
& \left.-\frac{S_{t}}{(1+E)^{t}}-\frac{K_{t}}{(1+E)^{t}}-\frac{M_{t}}{(1+E)^{t}}+\frac{\sum_{t=0}^{T}\left(-m_{t}-D_{t}+K_{t}\right)}{(1+E)^{t}}\right] P_{i} .
\end{aligned}
$$

The difference between financial and real options relates to the risk-free interest rate used for them. The first case involves the profitability of the asset which is least exposed to the repayment risk, i.e. short-term three-month government bonds. For real options, a similar interest rate is usually determined individually for each project, for example, the refinancing rate of central banks for projects with the lowest exposure, but more often - the average return on investments in the relevant industry.

Economically developed countries with the well regulated market economy widely use real options for items of real investment. It is very important for Russia to use real options when forming a portfolio of projects for real investment objects given the risk and uncertainty, in particular, for projects, when investors have little confidence in large and long-term private investment. It is noteworthy that the generation cost of a real option may turn out to be unreasonable. For example, an increase in the output (investment in additional production capacity) may be feasible due to the uncertain and doubtful demand for them.

Extraordinary real options can be used to protect real investments only provided a relevant method is invented for the purpose.

Thus, although initially the real options method meant the application of the option pricing technique to the management of an investment portfolio of real investments for purposes of its hedging, as the analysis of real options revealed, formulas for financial options should be seriously clarified to ensure unbiased results, since options with underlying real assets differ significantly from them.

Sorting out basic types of real options, managerial decision-makers expand a range of decisions they can make.

In a more unbiased formula is used to compute the expected effect of the investment project through real options, items of real investment can be more effectively hedged with real options given the risk and uncertainty, thus providing additional opportunities locked in investment projects for purposes of more effective development. 
Figure 1

Types of real options for real projects

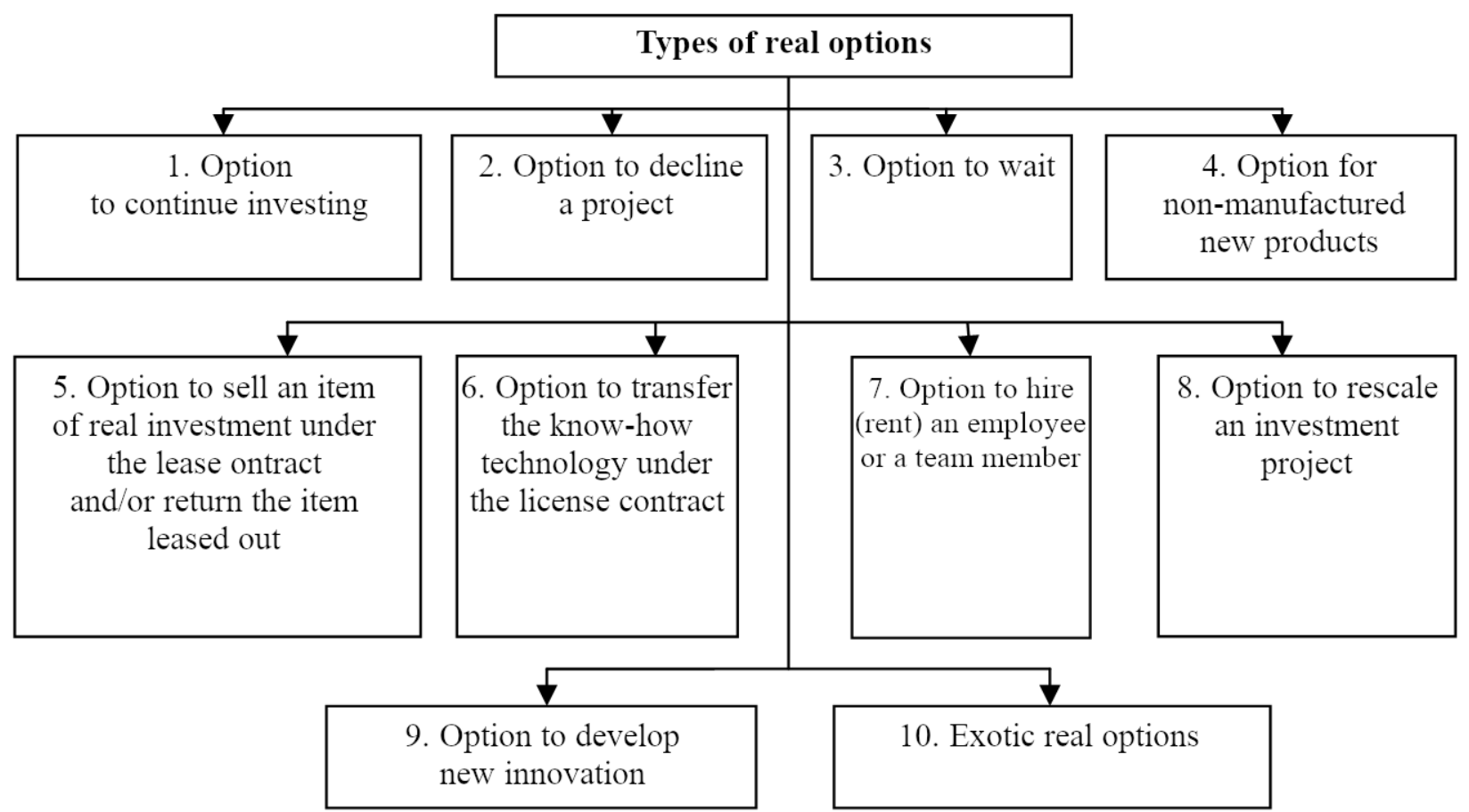

Source: Authoring

\section{Figure 2}

Stages of solutions for a real option to opt out of an innovation project

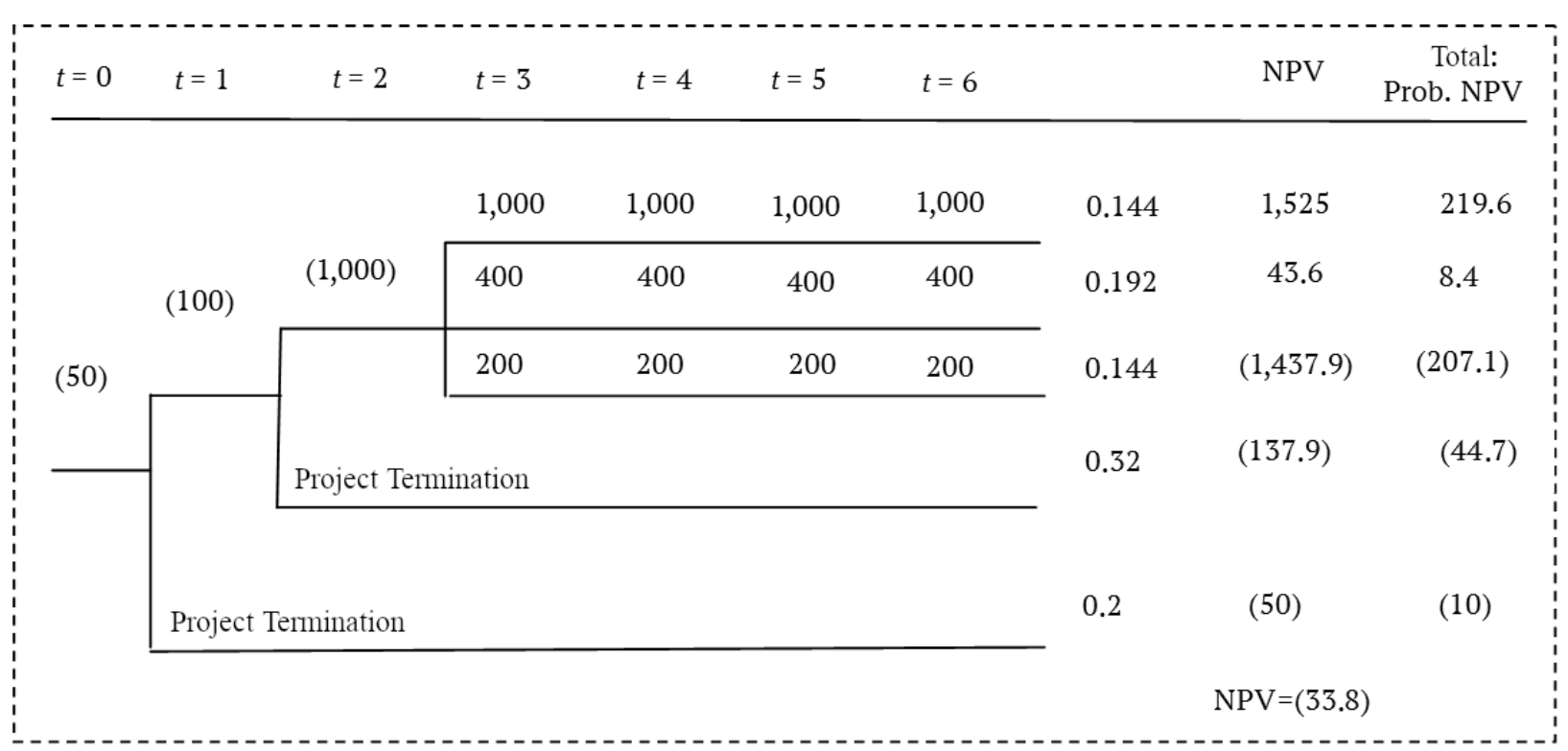

Source: Authoring 


\section{References}

1. Baranov A.O., Muzyko E.I. [The concept of real options as an innovative method of assessing the effectiveness of investment projects in industry]. Vestnik Novosibirskogo gosudarstvennogo universiteta. Ser.: Sotsial'no-ekonomicheskie nauki = Vestnik NSU. Ser.: Social and Economic Sciences, 2015, vol. 15, no. 1, pp. 32-51.

URL: https://cyberleninka.ru/article/n/kontseptsiya-realnyh-optsionov-kakinnovatsionnyy-metod-otsenki-effektivnosti-investitsionnyh-proektov-vpromyshlennosti (In Russ.)

2. Vitvitskii M.V. [Application of real options in the process of investment project evaluation]. Upravlencheskii uchet $i$ finansy, 2015, no. 1, pp. 70-79. (In Russ.)

3. Malyuga K.A. [Specific features of using the real options method in investment projects]. Nauchnoe obozrenie = Science Review, 2015, no. 2, pp. 229-235. (In Russ.)

4. Sedash T. [The real options method to evaluate investment projects in the field of energy conservation]. Finansovaya zhizn' $^{\prime}$ Financial Life, 2014, no. 3, pp. 62-65. (In Russ.)

5. Fedorova E.A. [Evaluation of investment projects in electrical power engineering using real options]. Ekonomicheskii analiz: teoriya i praktika $=$ Economic Analysis: Theory and Practice, 2015, no. 14, pp. 2-10.

URL: https://cyberleninka.ru/article/n/otsenka-investitsionnyh-proektov-v-oblastielektroenergetiki-s-pomoschyu-realnyh-optsionov/viewer (In Russ.)

6. Tsarenko V.A. [Use real options as a tool to the effectiveness evaluation of investment projects in the conditions of uncertainty and management flexibility]. T-Comm:

Telekommunikatsii i transport $=$ T-Comm, 2014, vol. 8, no. 7, pp. 87-91.

URL: https://cyberleninka.ru/article/n/ispolzovanie-realnyh-optsionov-kak-instrumentotsenki-effektivnosti-investitsionnyh-proektov-v-usloviyah-neopredelennosti-i/viewer (In Russ.)

7. Menassa C., Peña Mora F., Pearson N. Study of Real Options with Exogenous Competitive Entry to Analyze Dispute Resolution Ladder Investments in Architecture, Engineering and Construction Projects. Journal of Construction Engineering and Management, 2010, vol. 136, iss. 3, pp. 377-390.

URL: https://doi.org/10.1061/(ASCE)CO.1943-7862.0000132

8. Kokin A.S., Oskolkov I.M. [Theory of real options as acceptance paradigm investment decisions]. Audit i finansovyi analiz = Audit and Financial Analysis, 2015, no. 4, pp. 237-240. (In Russ.)

9. Krychowski C., Quélin B. Real Options and Strategic Investment Decisions: Can They Be of Use to Scholars? Academy of Management Perspectives, 2010, vol. 24, iss. 2, pp. 65-78. URL: https://www.jstor.org/stable/25682399 
10. Ying Fan, Lei Zhu. A Real Options Based Model and Its Application to China's Overseas Oil Investment Decisions. Energy Economics, 2010, vol. 32, iss. 3, pp. 627-637. URL: https://doi.org/10.1016/j.eneco.2009.08.021

11. Agafonov A.A. [Usage of real options in the implementation of hedging project financing risks]. Nauchnoe obozrenie = Science Review, 2015, no. 11, pp. 269-276. (In Russ.)

12. Filin S.A. Strakhovanie i khedzhirovanie riskov investitsionnoi deyatel'nosti [Insurance against risks and risk hedging in investment activities]. Moscow, Ankil Publ., 2009, 407 p.

13. Yakushev A.Zh. [Analysis of effectiveness and economic security of the project of construction water channel Caspian - Black/Azov Sea]. Natsional'nye interesy: prioritety i bezopasnost' $=$ National Interests: Priorities and Security, 2012, no. 43, pp. 14-20. URL: https://cyberleninka.ru/article/n/analiz-effektivnosti-iekonomicheskoy-bezopasnosti-proekta-stroitelstva-vodnogo-kanala-kaspiyskoechernoe-azovskoe-more/viewer (In Russ.)

14. Schilling M.A. Strategic Management of Technological Innovation. NY, Mcgraw-Hill Education, 2012, 336 p.

15. Kuznetsov D.V. [Real options in the formation of effective system of lease financing]. Den'gi i kredit $=$ Russian Journal of Money and Finance, 2014, no. 2, pp. 54-58. (In Russ.)

16. Filin S.A. Upravlenie investitsiyami v innovatsionnoi sfere ekonomiki $v$ usloviyakh riska i neopredelennosti: monografiya [Management of investments in the innovative sphere of economy in conditions of risk and uncertainty: a monograph]. Moscow, INITs Rospatenta Publ., 2014, 474 p.

17. Kaneva M.A. [Forecasting the scope of exotic options on the basis of the economic knowledge categories using the option methodology]. Vestnik Novosibirskogo gosudarstvennogo universiteta. Ser.: Sotsial'no-ekonomicheskie nauki = Vestnik NSU. Ser.: Social and Economic Sciences, 2008, vol. 8, no. 4, pp. 145-151. URL: https://cyberleninka.ru/article/n/prognoz-oblastey-primeneniya-ekzoticheskihoptsionov-na-osnove-kategoriy-ekonomicheskih-znaniy-ispolzuyuschih-optsionnuyu/ viewer (In Russ.)

18. Bukhvalov A.V. [Real options in management: Introduction to the problem]. Rossiiskii zhurnal menedzhmenta $=$ Russian Management Journal, 2004, no. 2, pp. 3-32.

URL: https://cyberleninka.ru/article/n/realnye-optsiony-v-menedzhmente-vvedenie-vproblemu/viewer (In Russ.) 


\section{Conflict-of-interest notification}

We, the authors of this article, bindingly and explicitly declare of the partial and total lack of actual or potential conflict of interest with any other third party whatsoever, which may arise as a result of the publication of this article. This statement relates to the study, data collection and interpretation, writing and preparation of the article, and the decision to submit the manuscript for publication. 